DOI: 10.32370/IA_2021_09_15

\title{
Social Dance as a Phenomenon of Modern Dance Practice
}

\author{
Zhuravlova Anastasia Volodymyrivna, \\ lecturer of the department of choreographic art \\ Kiev National University of Culture and Arts, \\ Kiev, Ukraine
}

The article is devoted to the study of social dance as a phenomenon of modern dance practice.

It is emphasized that in modern culture there is an increase in interest in social dance, which necessitates a theoretical understanding of this phenomenon in particular and dance culture in general from the standpoint of modern science, because at the moment its level does not correspond to the degree of practical interest in social dance.

It is stated that for most world civilizations, dance in general and social dance in particular, is one of the most important expressions of their worldview, which represents both historical and contemporary cultural values. And forms of movement illuminate and define gender, shape personal and group identity, and reflect and define political and religious status and aesthetic values.

Thanks to advances in the media, social dance is now one of the most popular pastimes in the world, combining dance forms of past centuries with new ones, such as hip-hop and contact improvisations.

The study found that the phenomenon of social dance in the context of dance practice in the XXI century. is an organic combination of elements of various areas of dance culture with the culture of modern society, as well as the promotion of philosophical and ideological paradigm of freedom of movement and communication in dance.

Keywords: social dance, phenomenon, dance practice, improvisation, bodily-spatial event.

Актуальність дослідження. Танець займає важливе місце в соціальній структурі всіх культур протягом всієї історії людства. Зазвичай танець визначається як спосіб людського вираження засобами руху або особливий художній рух, оснований на виразних рухах людського тіла, проте, не зважаючи на те, що рух дійсно є його фундаментальною особливістю, танець не варто зводити виключно до руху. У ряді теоретичних визначень танець позиціонується як свідомий спосіб ритмічних рухів тіла у визначеному обмеженому просторі, проте такі спортивно-кінезіологічні або художні теорії танцю зазвичай не враховують багато символічних аспектів танцю. У багатьох випадках вони зводять танець до його фізичного компоненту з точки зору естетично досконалої ритмічної фізичної активності і не акцентують на багатьох ролях та значеннях, які танець має у суспільстві, в якому виникає та існує. Враховуючи вищесказане, актуальним та важливим стає дослідження танцю як частини соціального життя та культурної практики. 
В сучасній культурі спостерігається підвищення інтересу до соціального танцю, що зумовлює необхідність теоретичного осмислення цього феномену зокрема i танцювальної культури в цілому з позицій сучасної гуманітаристики, оскільки на даний момент його рівень не відповідає ступеню практичного інтересу до оволодіння соціальним танцем.

Безумовно, соціальний танець не є абсолютно новим предметом дослідження, проте окремі питання не отримали відповідного висвітлення в просторі вітчизняної академічної школи.

Аналіз публікацій. На початку XXI ст. завдяки трансформаційним процесам, що відбувалися в світовій танцювальній практиці, в західному академічному просторі значно активізувалося наукове вивчення різноманітних аспектів соціального танцю як складного культурно-мистецького феномену сучасності. Для прикладу назвемо наукові публікації Дж. Скінер «Соціальний танець для успішної старості» [15], Б. КоенСтретунер «Соціальний танець: контекст та дефініція» («Social Dance: Contexts and Definitions») [8], дослідження К. Кноле «Сальса, Меренга, Бачара та їх величезний бум» («Salsa, Merengue, Bachata und deren enormer Boom») [9], С. Слоат «Карибський танець від Абакуа до ука: як дух формує ідентичність» («Caribbean Dance from Abakuá to Zouk: How Movement Shapes Identity») [16] та ін. Аналіз публікацій засвідчив і посилення наукового інтересу серед вітчизняних дослідників. Серед інших назвемо статті Р. Гриценюка «Соціальні танці в соціокультурному просторі XXI ст.: спортивнозмагальний аспект» [2], Д. Погибіль «Педагогіка соціального танцю в сучасному соціокультурному просторі» [5], О. Плахотнюка «Квітнесенція соціальних танців» [6] та ін.

У сучасному академічному вимірі дослідження соціального танцю позиціонують важливим інструментом для розуміння людства, оскільки спостереження та аналіз танцю в його культурному контексті $є$ центральним для вивчення культур і життєво важливим аспектом в міжкультурному дослідженні.

Дане дослідження спрямоване на розширення вітчизняної теоретичної бази для аналізу феномену соціального танцю.

Мета статті - визначити та розкрити різноманітні значення і нюанси соціального танцю в сучасних суспільствах. 
Виклад основного матеріалу. 3 антропологічної точки зору танець можна визначити як культурну практику і як соціальний ритуал, відповідно до якого танець розглядається як засіб естетичного задоволення і засіб встановлення зв'язків та певної структури в суспільстві [13, p. 132]. Танець як соціальний ритуал можна розглядати крізь призму символічних аспектів конкретної культури та процесів ідентифікації i диференціації через значення, як він виробляє для людей цієї культури.

Танець завжди має певне значення, що залежить від соціального середовища, в якому він з'являється: наприклад, якщо у певному танці партнер повертає партнерку під рукою, на денонативному рівні цей рух передає значення повороту, а на більш широкому культурному, конотативному рівні цей рух може свідчити про чоловіче домінування та жіноче підкорення, тобто про шовінізм і патріархальну культуру. Проте в окремих випадках цей рух може бути ознакою жіночого домінування і чоловічого преклоніння жінці, що означає матріархальну структуру суспільства $[12$, р. 7]. К. Сакс наголошує, що танець в усі часи і в усіх культурах - від магії та анамізму палеолітичної людини до корінних релігій африканських народів і племен; від давніх цивілізацій Сходу та давніх суспільства середньовічної Свропи до західних капіталістичних суспільств - тісно пов'язаний з життям конкретного суспільства, оскільки він є формою спілкування та невід'ємною частиною відтворення соціальної системи [14, p. 43]. За Бурдьє танець як особлива мова є соціально-історичним явищем, що залежить від простору і часу, в якому він існує, а також від тогочасних провладних структур [7, p. 4]. Т. Полхемус зазначає, що суспільства створюють танці і що танець насправді $є$ «метафізикою культури», тому, що культура конкретного суспільства втілена у формах матеріальної і фізичної культури, а остання також стилізована і схематизована у формі танцю [11, p. 8].

Науковці наголошують, що в процесі дослідження ролі танцю в соціальному житті доцільно виокремлювати два напрями: соціальний (побутовий) танець, який змінюється відповідно до культурним традиціям різних епох та аматорське хореографічне мистецтво, яке є дозвіллєвою діяльністю. Відповідно на сучасному етапі танець розвивається в напрямках професійного мистецтва, аматорського мистецтва та соціального танцю, який деякі дослідники називають тимчасовою категорією, оскільки кожна історична доба та соціальна група впливали на створення певного напряму танцю, відображалися на його стилістичних особливостях і створювали власні музично- 
хореографічні форми. Так, наприклад, В. Нікітін акцентує на існуванні певного протиставлення соціального танцю і танцю як виду мистецтва, що, на його думку, викликано семантичними причинами, оскільки один і той самий термін «сучасний танець» має різні значення. Дослідник наголошує, що головна відмінність полягає в тому, що аналіз танцю, який тісно пов'язаний з життям людського суспільства, дає зрозуміти, що в цій ролі танець існував протягом всієї історії людства, а аналіз танцю як виду мистецтва дає змогу точно визначити історичні межі зародження та розвитку того чи інщого напрямку, стилю або жанру танцювального мистецтва [3, с. 293].

На думку О. Плахотнюка, соціальний танець доцільно розглядати як «різновид парних танців, упорядкованих та кодифікованих для доступного виконавства та вивчення, що виокремились 3 бального та фольклорного танцю» [6, с. 29]; «нове сприйняття танцювальної культури сьогодення, основною якої є легке і невимушене танцювання будь-якого виду хореографії, що спрямоване на задоволення естетичних, соціальних й комунікативних задоволень потреб людини, а не заради професійного виконавства чи спортивних досягнень» $[6,29]$.

Зауважимо, що в академічному вимірі наразі не існує єдиного загальноприйнятого визначення поняття «соціальний танець», а його багатозначність вимагають обов'язкового уточнення який саме аспект танцювального феномену є предметом дослідження. Характерною тенденцією в країнах пострадянського простору $\epsilon$ ототожнення багатьма науковцями терміну «соціальний танець» та «побутовий танець» (підгрунтям цієї тенденції є переклад англомовного терміну «social», безпосередньо пов'язаного з соціумом та спілкуванням), що визначається як танець, що виконується в побуті для задоволення самих танцюристів. Проте, на думку Н. Осінцевої, подібне трактування не є коректним, оскільки дає підстави відносити до соціального танцю і народні танці, які також безпосередньо пов'язані з спілкуванням людей в певному соціумі у вільний час для особистого задоволення [4, с. 783].

Поділяючи думку дослідниці щодо неправомірності ототожнення термінів, які описують соціальний танець та необхідності виявлення його однозначного терміну, не зважаючи на протиріччя інтерпретації, що полягають в складності визначення генези даного явища як не лише продовження напряму який існував раніше, а нового явища у танцювальній культурі, яке наразі знаходиться на стадії активного становлення, у даному 
дослідженні розглядаємо соціальний танець як танець, що має соціальну функцію і контекст, а характерними ознаками є відсутність постійного танцювального партнера, варіативність послідовності рухів, імпровізація, об’єднання людей, які належить до різних культур та забезпечення їх комунікативної взаємодії і взаєморозуміння.

На думку французького філософа А. Бад’ю, танець - це єдине мистецтво, яке підкорене простору [1, с. 70]. У випадку соціального танцю сучасності, кожна пара, яка танцює на спільних майданчиках, створює власний простір для діалогу, результатом якого є створення унікальної невеличкої події, завжди нової і неповторної, що «призупиняє час і розгортається у просторі» [1, с. 68], відповідно партнери створюють специфічну тілесно-просторову подію.

Джерелами імпровізації в соціальному танці є онтологічна сутність танцю, яка спрямовує його до свободи:

- від усталених та/або кодифікованих танцювальних фігур;

- від професійних знань та високої /віртуозної техніки виконання;

- від соціальної ієрархії [4, с. 793].

Дослідники розглядають соціальний танець як транскультурну генезу святкового ритуального дійства, унікальну ритуалізовану практику сучасності, що, на відміну від багатьох інших явищ сучасної масової культури, має не північноамериканське, а південноамериканське та африканське походження i наголошують на тому, що походження ритмів соціального танцю безпосередньо пов'язано з революційним духом та карнавальною традицією, тобто традицією святкового ритуального дійства, неочевидною метою якого є мирне співіснування всіх культурних шарів [10, с. 9-10].

Важливими особливостями соціального танцю є те, що:

- соціальний танець не має автора хореографії, оскільки він створений людьми і саме зміни в укладі людського життя призводять до виникнення та популяризації нових рухів та фігур;

- соціальний танець репрезентує своєрідну картину переплетіння, протистояння, симбіозу та синтезу традицій, культур, ритмів, образів та міфів;

- функціональне призначення соціального танцю полягає в об'єднанні суспільства (за Б. Кохен-Стратінер одним з багатьох призначень соціального танцю $є$ зібрати всіх разом для того, щоб щось відсвяткувати) [8, р. 122] з метою святкування; 
- у соціальному танці відсутній постійний танцювальний партнер (як, наприклад, в бальному або спортивному бальному танці), що зумовлено прагненням до розширення комунікативної взаємодії;

- важливим аспектом соціального танцю є імпровізація - завдяки відсутності жорстко структурованої послідовності рухів танцюристи можуть виконувати різноманітні танцювальні варіації.

Соціальний танець характеризується унікальним процесом творчого вираження в реальній формі, оскільки позбавлений завдання створити твір мистецтва, не ставить за мету створення певного результату творчості, що несе певну ідею та створюється хореографом-творцем або групою хореографів.

Висновки. Цінності культури втілюються (в прямому і переносному сенсі) в їі танцювальних формах, і для більшості світових цивілізацій танець загалом і соціальний танець зокрема, є одним із найбільш важливих виразників їх світогляду, що репрезентує як історичні, так і сучасні культурні цінності. А форми руху освітлюють та визначають гендер, формують особисту і групову ідентичність, а також відображають і визначають політичній і релігійний статус та естетичні цінності.

Завдяки досягненням в галузі засобів масової інформації соціальний танець наразі $\epsilon$ одним із найбільш популярних розваг людей в усьому світі, поєднавши танцювальні форми минулих століть з новими, такими як хіп-хоп та контактна імпровізація.

Дослідження виявило, що феномен соціального танцю в контексті танцювальної практики XXI ст. полягає в органічному поєднанні елементів найрізноманітніших напрямів танцювальної культури 3 культурою сучасного суспільства, а також популяризації філософсько-світоглядної парадигми свободи руху та спілкування в танці.

\section{References}

1. Badiou, A. (2014). A small guide to aesthetics. St. Petersburg: Publishing House of the European University at St. Petersburg.

2. Gritsenyuk, R. A. (2020). Social dances in the socio-cultural space of the XXI century: sports and competitive aspect. Art notes, Issue 38, pp. 79-84.

3. Nikitin, V. Yu. (2014). Dance as a socio-cultural phenomenon. Three faces of Terpsichore. MGUKI newspaper, no. 6, pp. 292-298.

4. Osintseva, N. V. (2021). Philosophical understanding of modern social dance. Diploma, no 4, pp. 780-794. 
5. Pogubil D. O. (2013). Pedagogy of social dance in the modern socio-cultural space. Scientific journal of NPU named after MP Drahomanov. Series 14: Theory and methods of art education, Issue 15, pp. 173-177. 28-37.

6. Plahotniuk, O. (2018). The flowering of social dances. Dance studios, Issue. 1, pp.

7. Bourdieu, P. (1994). Language and Symbolic Power. Cambridge: Polity Press

8. Cohen-Stratyner, B. (2001). Social Dance: Contexts and Definitions. Dance Research Journal, Issue 33, pp. 121-124.

9. Knolle, C. (2008). Salsa, Merengue, Bachata und deren enormer Boom. Dissertation Dr. Phil. Wien. DOI: 10.25365/thesis.3197.

10. Lisina, L. (2012). Ontology of the cultural influence dance as a ritual. Context and reflection: philosophy about the world and man, no. 2-3, pp. 9-19.

11. Polhemus, T. (1993). Dance, Gender and Culture. In: Helen Thomas (ed.), Dance, Gender and Culture. London: Macmillan, pp. 3-15.

12. Pusnik, M. (2010). Introduction: Dance as Social Lifeand Cultural Practice. Antropological notebooks, Issue 16 (3), pp. 5-8.

13. Radcliffe-Brown, A. R. (1994). Struktura in funkcija v primitivni družbi [Structure and Function in Primitive Society]. Ljubljana: ŠKUC, Filozofska fakulteta.

14. Sachs, C. (1994). World History of the Dance. New York: W. W. Norton \& Company.

15. Skinner, J. (2013). Social Dance for Successful Aging. Anthropology \& Aging Quarterly, Vol. 34, Issue 1, pp. 18-29.

16. Sloat, S. (2005). Caribbean Dance from Abakuá to Zouk: How Movement Shapes Identity. Gainesville : University Press of Florida.

\section{Translation of the References to the author's language}

\section{Список використаних джерел}

1. Бадью А. Малое руководство по инэстетике / пер. с фр. Д. Ардамацкой, А. Магуна. Санкт-Петербург: издательствово Европейского университета в СанктПетербурге, 2014. 156 с.

2. Гриценюк Р. А. Соціальні танці в соціокультурному просторі XXI ст.: спортивно-змагальний аспект. Мистецтвознавчі записки: зб. наук. праць. 2020 Вип. 38 С. 79-84.

3. Никитин В. Ю. Танец как социокультурный феномен. Три лика Терпсихоры. Вестник МГУКИ. 2014. № 6. С. 292-298.

4. Осинцева Н .В. Филосовское осмысление современного социального танца. Грамота, 2021. № 4. С. 780-794. 
5. Погибіль Д. О. Педагогіка соціального танцю в сучасному соціокультурному просторі. Науковий часопис НПУ імені М. П. Драгоманова. Серія 14 : Теорія і методика мистецької освіти. 2013. Вип. 15. С. 173-177.

6. Плахотнюк О. Квітнесенція соціальних танців. Танцювальні студії : зб. наук. пр. 2018. Вип. 1. С. 28-37.

7. Bourdieu P. Language and Symbolic Power. Cambridge: Polity Press, 1994. 303 p.

8. Cohen-Stratyner B. Social Dance: Contexts and Definitions. Dance Research Journal. 2001. Issue 33. pp. 121-124.

9. Knolle C. Salsa, Merengue, Bachata und deren enormer Boom. Dissertation Dr. Phil. Wien, 2008. DOI: 10.25365/thesis.3197.

10. Lisina L. Ontology of the cultural influence dance as a ritual. Контекст и рефлексия: философия о мире и человеке. 2012. № 2-3. С. 9-19.

11. Polhemus T. Dance, Gender and Culture. In: Helen Thomas (ed.), Dance, Gender and Culture. London: Macmillan, 1993. pp. 3-15.

12. Pusnik M. Introduction: Dance as Social Lifeand Cultural Practice. Antropological notebooks. 2010. Issue 16 (3). pp. 5-8.

13. Radcliffe-Brown A. R. Struktura in funkcija v primitivni družbi [Structure and Function in Primitive Society]. Ljubljana: ŠKUC, Filozofska fakulteta, 1994. 244 p. $469 \mathrm{p}$.

14. Sachs C. World History of the Dance. New York: W. W. Norton \& Company, 1994.

15. Skinner J. Social Dance for Successful Aging. Anthropology \& Aging Quarterly. 2013. Vol. 34. Issue 1. pp. 18-29.

16. Sloat S. Caribbean Dance from Abakuá to Zouk: How Movement Shapes Identity. Gainesville : University Press of Florida, 2005. 442 p. 